\title{
THE COMPARATIVE EFFICACY OF CERTAIN CHEMICAL AND BOTANICAL ACARICIDESAGAINST TETRANYCHUS URTICAE ON ASHWAGANDHA
}

\author{
Priyanka Goyal \\ Department of Zoology, B.B.D. Govt. P.G. College, Chimanpura, Jaipur, India.
}

ABSTRACT: Comparative efficacy of certain chemical and botanical acaricides against the two-spotted spider mite, Tetranychus urticae Koch (Acari: Tetranychidae) major pests occurred on Ashwagandha was studied at B.B.D. Govt. P.G. College, Chimanpura, Jaipur during cropping year 2012-2013 and 2013-2014. Eight pesticides were evaluated against T. urticae infesting ashwagandha, out of which Fenazagnite $(.05 \%)$ was found to be the most effective in the present study where Propargite $(.05 \%)$ was recorded to be at par in effectiveness with Fenazagnite and NSKE was found to be most effective among the plant extracts and was at par with the treatment of Azadirachtin.

KEYWORDS: Tetranychus urticae, Ashwagandha, mite incidence, post treatment population.

\section{INTRODUCTION}

The two spotted spider mite (TSSM) Tetranychus urticae Koch (Acarina: Tetranychidae) is a major pest of Withania somnifera (L.) Dunal, commonly known as Ashwagandha, high value medicinal plant in traditional systems of medicine for centuries ${ }^{9,15,22}$. The rapid developmental rate and high reproductive potential of $T$. urticae allows them to achieve damaging population levels very quickly, so in order to control the population of T. urticae most fields are treated with acaricides such as Clofentezine, Hexythiazox, Fenbutain oxide and Tetradifon $t^{2,13}$. There are naturally available cheaper botanical pesticides such as Pyrrolizidine alkaloids (PAs) extracted from Lithospermum canescens (Pietrosiuk et al., 2003), Ocimum sanctum, Taxus needle extracts $^{3,4}$, Neem cake, Neem extracts ${ }^{6,12,17}$, NSKE foliar spray $^{18}$. Therefore, economic agriculture suggests that there is an urgent need to develop an effective control measures.

\section{MATERIALS AND METHODS}

Present study was conducted at B.B.D. Govt. P.G. College, Chimanpura to determine the comparative efficacy of certain chemical and botanical acaricides against the two-spotted spider mite, Tetranychus urticae of major pests occurred on Ashwagandha during the cropping year 2012-2013 and 2013-2014.

\section{General Details of Experiment:}

Sowing period : August 2012 to April 2013 and August 2013 to April 2014.

Design : Randomized Block Design

Replications : 3

Totals no. of plots : 27

Size of plot : $2 \mathrm{~m} \times 1.6 \mathrm{~m}$

Spacing : $20 \mathrm{~cm} \times 7.5 \mathrm{~cm}$

Treatments : 9 (including untreated check) 
as below:

\begin{tabular}{|llc|}
\hline T0 & Name of Pesticides & Concentration \\
\hline T1 & Karanj seed extract ( KSK) & 5.0 \\
\hline T2 & Calotropis leaf extract & 5.0 \\
\hline T3 & Neem seed kernel extract (NSKE) & 5.0 \\
\hline T4 & Datura leaf extract & 5.0 \\
\hline T5 & Azadirachtin & 5.0 \\
\hline T6 & Ethion 50 EC & 0.05 \\
\hline T7 & Propargite 57 EC & 0.05 \\
\hline T8 & Fenazagnite 10EC & 0.05 \\
\hline T9 & Untreated check & - \\
\hline
\end{tabular}

Evaluation of Chemicals against the Mite:

The treatment spray was done in the evening hours on the crop with the help of foot sprayer, when the mite population was sufficiently built up. First, one spray was applied, but due to the need arises, second spray was given. The population count of mite incidence were taken one day before and seven, ten and twenty days after the treatment (post treatment population). For finding out the efficacy of pesticides, the percent reduction in mite incidence, based on leaf curling, were subjected to ANOVA after transforming them to angular values. The percent reduction in different treatments was calculated by the formula given by Henderson and Tilton (1955).

Percentage reduction $=1-\left\{\frac{\mathrm{T}_{\mathrm{a}} \times \mathrm{C}_{\mathrm{b}}}{\mathrm{T}_{\mathrm{b}} \times \mathrm{C}_{\mathrm{a}}}\right\} \times 100$

Where,

$\mathrm{T}_{\mathrm{a}}=$ Number of mites after treatment.

$\mathrm{T}_{\mathrm{b}}=$ Number of mites before treatment.

$\mathrm{C}_{\mathrm{a}}=$ Number of mites in untreated control after treatment.

\section{RESULTS AND DISCUSSION}

Comparative efficacy of certain pesticides against Tetranychus urticae infesting Ashwagandha plants already established in the herbal garden of B.B.D. Govt College, Chimanpura, were carried out during cropping year 2012- 2013 and 201314. The observations on bioefficacy of certain pesticides against $T$. urticae were recorded after first spray and after second spray and the data obtained are presented here. 
Table 1: Bioefficacy of commonly used pesticides against Tetranychus urticae on ashwagandha during the cropping year 2012-13

\begin{tabular}{|c|c|c|c|c|c|c|c|}
\hline \multirow[t]{2}{*}{ Treatments } & \multirow{2}{*}{$\begin{array}{l}\text { Mean mite } \\
\text { incidence } \\
\text { before } \\
\text { treatment }\end{array}$} & \multicolumn{3}{|c|}{ After first spray } & \multicolumn{3}{|c|}{ After second spray } \\
\hline & & 7 DAS & 10 DAS & 20 DAS & 7 DAS & 10 DAS & 20 DAS \\
\hline $\begin{array}{l}\text { Karanj seed extract } \\
(\mathrm{KSK})\end{array}$ & $\begin{array}{c}1.323 \\
(1.113)^{*}\end{array}$ & $\begin{array}{c}62.460 \\
(52.223)\end{array}$ & $\begin{array}{c}70.156 \\
(56.893)\end{array}$ & $\begin{array}{c}79.680 \\
(63.197)\end{array}$ & $\begin{array}{c}38.053 \\
(38.050)\end{array}$ & $\begin{array}{c}32.266 \\
(34.570)\end{array}$ & $\begin{array}{c}58.370 \\
(49.837)\end{array}$ \\
\hline $\begin{array}{l}\text { Calotropis leaf } \\
\text { extract }\end{array}$ & $\begin{array}{c}1.330 \\
(1.113)^{*}\end{array}$ & $\begin{array}{c}63.556 \\
(52.883)\end{array}$ & $\begin{array}{c}70.416 \\
(57.063)\end{array}$ & $\begin{array}{c}79.906 \\
(63.367)\end{array}$ & $\begin{array}{c}38.713 \\
(38.467)\end{array}$ & $\begin{array}{c}32.623 \\
(34.817)\end{array}$ & $\begin{array}{c}59.606 \\
(50.537)\end{array}$ \\
\hline $\begin{array}{l}\text { Neem seed kernal } \\
\text { extract (NSKE) }\end{array}$ & $\begin{array}{c}1.327 \\
(1.12)^{*}\end{array}$ & $\begin{array}{c}64.610 \\
(53.517)\end{array}$ & $\begin{array}{c}71.726 \\
(57.887)\end{array}$ & $\begin{array}{c}80.646 \\
(63.923)\end{array}$ & $\begin{array}{c}39.036 \\
(38.650)\end{array}$ & $\begin{array}{c}33.310 \\
(35.240)\end{array}$ & $\begin{array}{c}62.733 \\
(52.377)\end{array}$ \\
\hline Datura leaf extract & $\begin{array}{c}1.317 \\
(1.117)^{*}\end{array}$ & $\begin{array}{c}63.057 \\
(52.580)\end{array}$ & $\begin{array}{c}70.090 \\
(56.853)\end{array}$ & $\begin{array}{c}79.713 \\
(63.220)\end{array}$ & $\begin{array}{c}38.003 \\
(38.047)\end{array}$ & $\begin{array}{c}32.990 \\
(35.057)\end{array}$ & $\begin{array}{c}58.843 \\
(50.117)\end{array}$ \\
\hline Azadirachtin & $\begin{array}{c}1.323 \\
(1.117)^{*}\end{array}$ & $\begin{array}{c}64.360 \\
(53.363)\end{array}$ & $\begin{array}{c}71.100 \\
(57.503)\end{array}$ & $\begin{array}{c}80.290 \\
(63.623)\end{array}$ & $\begin{array}{c}38.923 \\
(38.590)\end{array}$ & $\begin{array}{c}33.143 \\
(35.127)\end{array}$ & $\begin{array}{c}60.960 \\
(51.337)\end{array}$ \\
\hline Ethion $50 \mathrm{EC}$ & $\begin{array}{c}1.33 \\
(1.117)^{*}\end{array}$ & $\begin{array}{c}68.886 \\
(56.113)\end{array}$ & $\begin{array}{c}76.156 \\
(60.800)\end{array}$ & $\begin{array}{c}85.426 \\
(67.567)\end{array}$ & $\begin{array}{c}39.760 \\
(39.077)\end{array}$ & $\begin{array}{c}33.606 \\
(35.413)\end{array}$ & $\begin{array}{c}66.380 \\
(54.587)\end{array}$ \\
\hline Propargite 57 EC & $\begin{array}{c}1.323 \\
(1.113)^{*}\end{array}$ & $\begin{array}{c}68.536 \\
(55.887)\end{array}$ & $\begin{array}{c}75.676 \\
(60.443)\end{array}$ & $\begin{array}{c}84.730 \\
(67.027)\end{array}$ & $\begin{array}{c}42.563 \\
(40.723)\end{array}$ & $\begin{array}{c}39.686 \\
(39.050)\end{array}$ & $\begin{array}{c}71.826 \\
(57.933)\end{array}$ \\
\hline Fenazagnite 10EC & $\begin{array}{c}1.310 \\
(1.113)^{*}\end{array}$ & $\begin{array}{c}68.310 \\
(55.760)\end{array}$ & $\begin{array}{c}75.430 \\
(60.290)\end{array}$ & $\begin{array}{c}85.203 \\
(67.373)\end{array}$ & $\begin{array}{c}42.233 \\
(40.510)\end{array}$ & $\begin{array}{c}41.200 \\
(39.950)\end{array}$ & $\begin{array}{c}74.300 \\
(59.560)\end{array}$ \\
\hline Untreated & $\begin{array}{c}1.333 \\
(1.117)^{*} \\
\end{array}$ & - & - & - & - & - & - \\
\hline $\mathrm{SEM}_{ \pm}$ & $(0.0023)$ & $(0.288)$ & $(0.225)$ & $(0.201)$ & $(0.701)$ & $(1.19)$ & $(0.637)$ \\
\hline $\mathrm{CD}$ at $5 \%$ & NS & $(0.873)$ & $(0.684)$ & $(0.608)$ & NS & (3.619) & $(1.93)$ \\
\hline
\end{tabular}

DAS = Days after spray

values in parentheses are angular transformed values, $*=$ values are under root transformed values. 
Table 2: Bioefficacy of commonly used pesticides against Tetranychus urticae on ashwagandha during the cropping year 2013-14

\begin{tabular}{|c|c|c|c|c|c|c|c|}
\hline \multirow[t]{2}{*}{ Treatments } & \multirow{2}{*}{$\begin{array}{l}\text { Mean mite } \\
\text { incidence } \\
\text { before } \\
\text { treatment }\end{array}$} & \multicolumn{3}{|c|}{ After first spray } & \multicolumn{3}{|c|}{ After second spray } \\
\hline & & 7 DAS & 10 DAS & 20 DAS & 7 DAS & 10 DAS & 20 DAS \\
\hline $\begin{array}{l}\text { Karanj seed extract } \\
\text { (KSK) }\end{array}$ & $\begin{array}{c}1.450 \\
(1.203)^{*}\end{array}$ & $\begin{array}{c}42.003 \\
(40.410)\end{array}$ & $\begin{array}{c}61.766 \\
(51.803)\end{array}$ & $\begin{array}{c}73.466 \\
(58.997)\end{array}$ & $\begin{array}{c}44.536 \\
(41.857)\end{array}$ & $\begin{array}{c}57.890 \\
(49.567)\end{array}$ & $\begin{array}{c}70.73 \\
(57.257)\end{array}$ \\
\hline $\begin{array}{l}\text { Calotropis leaf } \\
\text { extract }\end{array}$ & $\begin{array}{c}1.457 \\
(1.203)^{*}\end{array}$ & $\begin{array}{c}43.446 \\
(41.240)\end{array}$ & $\begin{array}{c}62.240 \\
(52.103)\end{array}$ & $\begin{array}{c}74.590 \\
(59.720)\end{array}$ & $\begin{array}{c}45.710 \\
(42.533)\end{array}$ & $\begin{array}{c}58.053 \\
(49.623)\end{array}$ & $\begin{array}{l}71.296 \\
(57.610)\end{array}$ \\
\hline $\begin{array}{l}\text { Neem seed kernal } \\
\text { extract (NSKE) }\end{array}$ & $\begin{array}{c}1.453 \\
(1.203)^{*}\end{array}$ & $\begin{array}{c}46.360 \\
(42.913)\end{array}$ & $\begin{array}{c}63.770 \\
(53.013)\end{array}$ & $\begin{array}{c}75.910 \\
(60.623)\end{array}$ & $\begin{array}{c}46.093 \\
(42.740)\end{array}$ & $\begin{array}{c}58.720 \\
(50.033)\end{array}$ & $\begin{array}{c}72.006 \\
(58.060)\end{array}$ \\
\hline Datura leaf extract & $\begin{array}{c}1.450 \\
(1.203)^{*}\end{array}$ & $\begin{array}{c}42.303 \\
(40.567)\end{array}$ & $\begin{array}{c}61.320 \\
(51.550)\end{array}$ & $\begin{array}{c}73.546 \\
(59.040) \\
\end{array}$ & $\begin{array}{c}43.820 \\
(41.437)\end{array}$ & $\begin{array}{c}58.173 \\
(49.700)\end{array}$ & $\begin{array}{c}71.163 \\
(57.527)\end{array}$ \\
\hline Azadirachtin & $\begin{array}{c}1.460 \\
(1.203)^{*}\end{array}$ & $\begin{array}{c}44.346 \\
(41.743)\end{array}$ & $\begin{array}{c}63.190 \\
(52.677)\end{array}$ & $\begin{array}{l}75.170 \\
(60.113)\end{array}$ & $\begin{array}{c}45.793 \\
(42.593)\end{array}$ & $\begin{array}{c}58.526 \\
(49.913)\end{array}$ & $\begin{array}{c}71.716 \\
(57.883)\end{array}$ \\
\hline Ethion $50 \mathrm{EC}$ & $\begin{array}{c}1.460 \\
(1.137)^{*}\end{array}$ & $\begin{array}{c}52.930 \\
(46.700)\end{array}$ & $\begin{array}{l}69.360 \\
(56.393)\end{array}$ & $\begin{array}{c}80.846 \\
(64.040)\end{array}$ & $\begin{array}{c}50.726 \\
(45.423)\end{array}$ & $\begin{array}{c}62.136 \\
(52.020)\end{array}$ & $\begin{array}{l}80.266 \\
(63.630)\end{array}$ \\
\hline Propargite 57 EC & $\begin{array}{c}1.453 \\
(1.137)^{*}\end{array}$ & $\begin{array}{c}50.916 \\
(45.517)\end{array}$ & $\begin{array}{c}68.076 \\
(55.617)\end{array}$ & \begin{tabular}{|c|}
80.493 \\
$(63.797)$
\end{tabular} & $\begin{array}{c}54.356 \\
(47.527)\end{array}$ & $\begin{array}{c}64.066 \\
(53.170)\end{array}$ & $\begin{array}{c}81.636 \\
(64.627)\end{array}$ \\
\hline Fenazagnite 10EC & $\begin{array}{c}1.463 \\
(1.137)^{*}\end{array}$ & $\begin{array}{c}50.900 \\
(45.517)\end{array}$ & $\begin{array}{c}67.736 \\
(55.390)\end{array}$ & $\begin{array}{c}80.526 \\
(63.820)\end{array}$ & $\begin{array}{c}52.050 \\
(46.183)\end{array}$ & $\begin{array}{c}66.996 \\
(54.937)\end{array}$ & $\begin{array}{c}84.773 \\
(67.050)\end{array}$ \\
\hline Untreated & $\begin{array}{c}1.463 \\
(1.137)^{*} \\
\end{array}$ & - & - & - & - & - & - \\
\hline $\mathrm{SEM}_{ \pm}$ & $(0.0351)$ & $(0.294)$ & $(0.204)$ & $(0.18)$ & $(0.444)$ & $(0.307)$ & $(0.438)$ \\
\hline $\mathrm{CD}$ at $5 \%$ & NS & $(0.891)$ & $(0.618)$ & $(0.557)$ & $(1.343)$ & $(0.932)$ & (1.328) \\
\hline
\end{tabular}

DAS = Days after spray

values in parentheses are angular transformed values, *= values are under root transformed values. 
Table 3: Bioefficacy of commonly used pesticides against Tetranychus urticae on ashwagandha pooled mean of the cropping year 2012-13 and 2013-14

\begin{tabular}{|l|c|c|c|c|c|c|}
\hline \multirow{2}{*}{ Treatments } & \multicolumn{3}{|c|}{ After first spray } & \multicolumn{3}{c|}{ After second spray } \\
\cline { 2 - 7 } & 7 DAS & 10 DAS & 20 DAS & 7 DAS & 10 DAS & 20 DAS \\
\cline { 2 - 7 } & & & & & & \\
Karanj seed extract & 52.232 & 65.961 & 76.573 & 41.295 & 45.078 & 64.55 \\
(KSK) & $(46.317)$ & $(54.348)$ & $(61.097)$ & $(39.953)$ & $(42.068)$ & $(53.547)$ \\
\hline Calotropis leaf & 53.501 & 66.328 & 77.248 & 42.212 & 45.338 & 65.451 \\
extract & $(47.062)$ & $(54.583)$ & $(61.543)$ & $(40.500)$ & $(42.222)$ & $(54.073)$ \\
\hline Neem seed kernal & 55.485 & 67.748 & 78.278 & 42.565 & 46.015 & 67.369 \\
extract (NSKE) & $(48.215)$ & $(55.450)$ & $(62.273)$ & $(40.695)$ & $(42.637)$ & $(55.218)$ \\
\hline Datura leaf extract & 52.680 & 65.705 & 76.630 & 40.912 & 45.582 & 65.003 \\
& $(46.574)$ & $(54.202)$ & $(61.130)$ & $(39.742)$ & $(42.378)$ & $(53.822)$ \\
\hline Azadirachtin & 54.353 & 67.145 & 77.730 & 42.358 & 45.835 & 66.338 \\
& $(47.553)$ & $(55.090)$ & $(61.868)$ & $(40.592)$ & $(42.520)$ & $(54.610)$ \\
\hline Ethion 50 EC & 60.908 & 72.758 & 83.136 & 45.243 & 47.871 & 73.323 \\
& $(51.407)$ & $(58.600)$ & $(65.803)$ & $(42.250)$ & $(43.717)$ & $(59.108)$ \\
\hline Propargite 57 EC & 59.726 & 71.876 & 82.612 & 48.460 & 51.876 & 76.731 \\
& $(50.702)$ & $(58.030)$ & $(65.412)$ & $(44.125)$ & $(46.110)$ & $(61.280)$ \\
\hline Fenazagnite 10EC & 59.605 & 71.583 & 82.865 & 47.142 & 54.098 & 79.536 \\
& $(50.638)$ & $(57.840)$ & $(65.597)$ & $(43.347)$ & $(47.443)$ & $(63.305)$ \\
\hline SEM & $(0.381)$ & $(0.242)$ & $(0.226)$ & $(0.706)$ & $(0.968)$ & $(0.636)$ \\
\hline CD at 5\% & $(1.094)$ & $(0.695)$ & $(0.648)$ & $(2.026)$ & $(2.779)$ & $(1.827)$ \\
\hline
\end{tabular}

DAS $=$ Days after spray

values in parentheses are angular transformed values, $*=$ values are under root transformed values. 


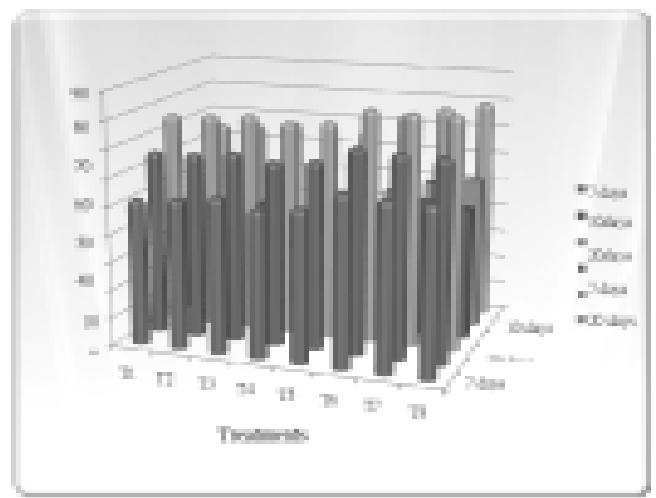

Fig.: Bioefficacy of commonly used pesticides against Tetranychusurticae on ashwagandha pooled mean of the cropping year 2012-13 and 2013-14.

Out of eight pesticides evaluated against $T$. urticae infesting ashwagandha, Fenazagnite $(.05 \%)$ was found to be the most effective in the present study. Propargite $(.05 \%)$ was found to be at par in effectiveness with Fenazagnite which is in agreement with Agrawal ${ }^{1}$. The next best pesticide was observerd as Dicofol.. Yadav et $a l .{ }^{23}$ studied the efficacy of some insecticide/acaricides against $T$. urticae on brinjal crop at Pili Kothi farm, T.D. College, Jaunpur. The highest average mortality recorded in Dicofol (18.5 EC) was 92.53 percent followed by Dicofol (5 WP) (87.14\%), Propargite (86.66\%), Abamectin (81.06\%), Ethion (77.18\%), Phosalone (76.39\%), Fenpropathrin (70.59\%) and Endosulfan (72.83\%). Least mortality was observed in Sulphur (37.18\%). Ramaraju (2004) studied the bioefficacy of different acaricides and TNAU neem oils against $T$. urticae on bhindi and found Dicofol $0.05 \%$ as the most effective causing 70.56 to 91.85 per cent reduction of mites.In the present study, NSKE was found to be most effective among the plant extracts and was at par with the treatment of Azadirachtin. The present finding is in agreement with Jhala et $a .^{8}$ who studied various plant extracts for their ovicidal and adulticidal action against red spider mite, T. cinnabarinus on okra and found NSKE 5\% (W/V) most effective against the mite causing $71.4 \%$ mortality. Likewise, Sandnya et al. also reported that NSKE $(5 \%)$ proved to be the best of the treatments conductedso far in maintaining the lower levels of larval population as the population continuously decreased from 1.07 to 0.716 in 14 days as compared to control. Whereas, Kumaran et al. ${ }^{10}$ also reported that Azadirachtin 1\% (Neemazal) was effective against $T$. urticae and recorded the highest per cent reduction of 70.16 and 70.95 over the untreated check in first and second season,respectively. The present findings are in partially confirmation with Singh et al., (2004) who tested the efficacy of Dicofol $(0.02 \%)$, Propargite $(0.08,0.11$ and $0.17 \%)$, Monocrotophos (0.05\%)and NSKE (5\%) against mite $T$. cinnabarinus infesting okra. NSKE and Monocrotophos reduced the population significantly as compared to untreated control but was less effective than Dicofol and Propargite. Whereas, Mani et al. ${ }^{11}$ reported that acaricides and botanical pesticides were found effective against two spotted spider mite on okra crop and could significantly reduce the mite population. The maximum mortality $(89.5 \%)$ of adult two spotted spider mite occurred when treated 
with Dicofol $18.5 \%$. In case of botanical pesticides, Azadirachtin gave good response and caused up to $50 \%$ mortality.Neem extracts are repellant and antifeedant effect on pests ${ }^{6,12,17}$. Srinivasa and Sugeetha ${ }^{19}$ conducted a field experiment to evaluate the bioefficacy of certain botanicals/ acaricides against $T$. urticae on okra. Yathiraj and Jagadish ${ }^{24}$ tested some plant extracts viz., Azadirachta indica, Clerodendron inermae, Duranta repens, Eucalyptus globules Leucas aspera and Vitex negundo for their suitability in integrated management of T.urticae Singh et $a l .{ }^{18}$ tested the efficacy of Dicofol $(0.02 \%)$, Propargite (0.08, 0.11 and $0.17 \%)$, Monocrotophos $(0.05 \%)$ and NSKE $(5 \%)$ against mite, $T$. cinnabarinus infesting okra. Minimum mortality was observed with Propargite 0.17 and $0.11 \%$ (49.1 and 53.3 $7 / 3$ leaves) and Dicofol (56.7/3 leaves) at seven days after treatment. However, NSKE and Monocrotophos reduced the population significantly as compared to untreated control but was less effective than Dicofol and Propargite. Kumaran et al. ${ }^{\mathbf{1 0}}$ reported that Azadirachtin 1\% (Neemazal) was effective against $T$. urticae and recorded the highest per cent reduction of 70.16 and 70.95 over the untreated check in first and second season respectively. Vinoth Kumar et $a l .{ }^{21}$ evaluated the effect of organic sources of nutrients in combination with foliar application of entomopathogenic fungi and certain botanical pesticides against $T$. urticae.

\section{REFERENCES}

1. Agrawal, V.K., 1990. Efficacy of some pesticides against Eriophid mite on pomegranate. Abs in $4^{\text {th }}$ National Symposium on Acarology held from Oct 12-14, at Calicut, pp. 70.

2. DeAngelis, J., R.E. Berry and G.W. Krantz, 1983. Photosynthesis, leaf conductance, and leaf chlorophyll content in spider mite (Acari: Tetranychidae) injury of peppermint leaves. Env. Ent., 12: 345-348.

3. Furmanowa, M., D. Kropczynska, A. Zobel, K. Glowniak, J. Jozefowicz, A. Sahajdak, J. Guzewska, A. Jozefczyk and L. Rapczewska, 2001. Effect of water extracts from needle surface of Taxus baccata var. elegantissima on life history parameters of two spotted spider mite (T. urticae Koch). Herb. Polon., 47: 5-10.

4. Furmanowa, M., D. Kropczynska, A. Zobel, K. Glowniak, H. Oledzka, J. Jozefowicz, A. Sahajdak and A. Jozefczyk, 2002. Influence of water extracts from the surface of two new (Taxus) species on mites (T. urticae Koch). J. Appl. Toxicol., 22: 107-109.

5. Grafton-Cardwell, E.E., Y. Ouyang and R.A. Striggow, 1997. Predaceous mite (Acari: Phytoseiidae) for control of spider mites (Acari: Tetranychidae) in nursery citrus. Env. Entomol., 26: 121-130.

6. Gripwell, E., 1999. The effect of neem based insecticide on three important greenhouses pests. IOBC Bull./Bull. OILB22, pp. 97-100.

7. Henderson, C.F. and E.W. Tilton, 1955. Test acaricides against the brown wheat mite. $J$. Eco. Ento., 48: 157-161.

8. Jhala, R.C., B.D. Patel and T.M. Bharpoda, 1998. Ovicidal and adulticidal efficacy of various plant extracts against red spider mite, Tetranychus cinnabarinus on okra. In Proceeding of the Seminar on Entomology in 21st Century, 30th April to 2nd May, 1988 by Ecological Society of India, RCA, Udaipur, pp. 44-46.

9. Kaur, K., G. Rani, N. Widodo, A. Nagpal, K. Taira, S.C. Kaul and R. Wadhwa, 2004. 
Evaluation of the anti-proliferative and antioxidative activities of leaf extract from in vivo and in vitro raised Ashwagandha. Food and Chemical Toxicol., 42(12): 2015-2020.

10. Kumaran, N., S. Douressamy and K. Ramaraju, 2007. Bioefficacy of botanicals to two spotted spider mite, Tetranychus urticae Koch. infesting okra. Pestology, 31(9): 43-49.

11. Mani, C., S. Kumar and R.N. Singh, 2003. Efficacy of Acaricides and botanicals against two spotted mite, Tetranychus urticae Koch on okra. Ann. Pl. Protec. Sci., 11(1): 153154.

12. Mansour, F.A. and K.R.S. Ascher, 1995. Acarina mites. In the neem Tree, (ed. Schmutterer H). VCH: Weinheim, pp. 161-166.

13. Morris, M.A., B.A. Croft and R.E. Berry, 1996. Overwintering and effects of autumn habitat manipulation and carbofuran on Neoseiulus fallacis and T. urticae in pepper mint. Exp. App. Acarol., 20: 249-258.

14. Pietrosiuk, A., M. Furmanowa, D. Kropczynska, B. Kawka and H. Wiedenfeld, 2003. Life history parameters of the two spotted spider mite feeding on bean leaves treated with Pyrrolizidine Alkaloids. J. Appl. Toxicol. 23: 187-190.

15. Rege, N.N., U.M. Thatte and S.A. Dahanukar, 1999. Adaptogenic properties of six rasayana herbs used in Ayurvedic Medicine. Phytotherapy Res., 13(4): 275-291.

16. Sandnya, D., G. Jayant, B. Prasad and T.P. Rajendran, 2003. Comparative Evaluation of botanical and bioagent formulations against Helicoverpa armigera Hubner. in chickpea crop under central Indian conditions. Pestology, 27(10): 19-21.

17. Schmutter, H., 1990. Properties and potential of natural pesticides from the neem tree,
Azadirachta indica. Annu. Rev. Ento., 35: 271-297.

18. Singh, D.K., H.R. Sardana and L.N. Kadu, 2004. Efficacy of certain pesticides against red spider mite. Tetranychus cinnabarinus Koch. infesting okra. Indian J. Ent., 66(3): 282284.

19. Srinivasa, N. and G. Sugeetha, 1999. Bioeffectiveness of certain botanical and synthetic pesticides against okra spider mite. J. Acarol., 15(1\&2): 1-5.

20. Srivastava, B.K. and L.M.L. Mathur, 1962. Bionomics and control of the castor mite. Indian J. Ento., 24: 229-235.

21. Vinoth Kumar, S., C. Chinniah, C. Muthiah and A. Sadasakthi, 2009. Biorationals in the management of two spotted spider mite, Tetranychus urticae Koch in brinjal. Karnataka J. Agri. Sci., 22(3 spl issue): 682684.

22. Widodo, N., K. Kaur, B.G. Shrestha, Y. Takagi, T. Ishii, R. Wadhwa and S.C. Kaul, 2007. Selective killing of cancer cells by leaf extract of Ashwagandha: Identification of a tumor-inhibitory factor and the first molecular insights to its effect. Clinical Cancer Res., 13(7): 2298-2306.

23. Yadav, S.C. and M.K. Tripathi, 2014. Efficacy of some insecticides/acaricides for the management of Tetranychus urticae on brinjal crop. In abstract book of international conference on entomology, department of zoology and environmental sciences, Punjabi university, Patiala held on February 21-23, 2014. pp. 125.

24. Yathiraj, B.R. and P.S. Jagdish, 1999. Plant extracts future promising tools. In the integrated management of spider mite, Tetranychus urticae (Acari: Tetranychidae). J. Acarology, 15 (1): 40-43. 